\title{
Supporting Information for Identification of a Peptoid Inhibitor of the Proteasome 19S Regulatory Particle
}

\author{
Hyun-Suk Lim, Chase T. Archer, \& Thomas Kodadek*
}

Division of Translational Research, Departments of Internal Medicine and Molecular Biology, University of Texas Southwestern Medical Center, 5323 Harry Hines Blvd. Dallas, TX 75390-9185

General Remarks. All chemicals and solvents were purchased from commercial suppliers and used without further purification. TentaGel macrobeads (140-170 um diameter, $0.51 \mathrm{mmol} / \mathrm{g}$ capacity, Rapp Polymere) were used to construct the library. Resynthesis of the hits was performed on Rink Amide MBHA resin (Nova Biochem).

Synthesis of 6-(9H-purin-6-ylamino)hexanoic acid (capping molecule). A solution of 6-chloro-9Hpurine $(6.47 \mathrm{mmol}), 6$-aminohexanoic acid $(11.6 \mathrm{mmol})$ and sodium carbonate $(6.47 \mathrm{mmol})$ in water $(10$ $\mathrm{ml}$ ) was refluxed for $3 \mathrm{hr}$. After cooling to room temperature, the mixture was adjusted to $\mathrm{pH} 5$ by adding $1 \mathrm{~N} \mathrm{HCl}$. The resulting solid was filtered, washed with water and ethanol, and dried to yield 6(9H-purin-6-ylamino)hexanoic acid $(93 \%)$ as a cream color solid. ${ }^{1} \mathrm{H}$ NMR $\left(300 \mathrm{MHz}\right.$, DMSO-d $\mathrm{d}_{6}$, ppm): $8.15(\mathrm{~s}, 1 \mathrm{H}), 8.06(\mathrm{~s}, 1 \mathrm{H}), 7.48(\mathrm{br} \mathrm{s}, 1 \mathrm{H}), 3.44(\mathrm{br} \mathrm{s}, 2 \mathrm{H}), 2.19(\mathrm{t}, 2 \mathrm{H}, \mathrm{J}=6.9 \mathrm{~Hz}), 1.62-1.46(\mathrm{~m}$, $4 \mathrm{H}), 1.35-1.28(\mathrm{~m}, 2 \mathrm{H}) . \mathrm{MS} \mathrm{m} / \mathrm{z} 250[\mathrm{M}+1]^{+}$.

Purine-Capped Peptoid Library. The 5-mer peptoid library with two constant C-terminal Nlys (diaminobutane) residues was synthesized by split-and-pool method on TentaGel macrobeads $(1.0 \mathrm{~g}$, $0.51 \mathrm{mmol})$ using sub-monomer approach by a microwave-assisted protocol $(1,2)$. To the library beads, a solution of $3 \mathrm{ml}$ of O-benzotriazole-N,N,N',N'-tetramethyl-uronium-hexafluoro-phosphate (HBTU) $(0.4 \mathrm{mmol})$ in $0.8 \mathrm{M} \mathrm{N}$-methylmorpholine in DMF and $3 \mathrm{ml}$ of Boc-Lys(Fmoc)-OH (0.4 M) in DMF was added. The mixture was stirred at $220 \mathrm{rpm}$ on a shaker for $2 \mathrm{hr}$ at room temperature. The beads were washed 7 times with DMF. To the beads, a $20 \%$ solution $(4 \mathrm{ml})$ of piperidine in DMF was added and stirred for $20 \mathrm{~min}$ at room temperature. After a thorough wash with DMF, a solution $(2 \mathrm{ml})$ of 1hydroxybenzotriazole $(0.4 \mathrm{M})$ in $0.4 \mathrm{M}$ N-methylmorpholine in DMSO, 6-(9H-purin-6ylamino)hexanoic acid $(0.4 \mathrm{M})$ in DMSO $(2 \mathrm{ml})$ and 1-[3-(dimethylamino)propyl]-3-ethylcarbodiimide $(0.4 \mathrm{mmol})$ were added. The mixture was stirred at $220 \mathrm{rpm}$ overnight at room temperature. After thorough washing the beads with DMSO and dichloromethane, a solution $(3 \mathrm{ml})$ of $95 \%$ trifluoroacetic acid, $2.5 \%$ triisopropylsilane and $2.5 \%$ water was added and stirred for $2 \mathrm{hr}$. The solution was drained and library beads were washed with DMF 7 times. The beads were then washed thoroughly with dichloromethane, followed by DMF, neutralized with $20 \%$ diisopropylethylamine (DIPEA) in DMF, rinsed with dichloromethane again.

Screening of the peptoid library. The capped peptoid library displayed on TentaGel macrobeads ( $\sim 100,000$ beads) were swollen in DMF for $2 \mathrm{hr}$ and washed with TBST $(50 \mathrm{mM}$ Tris, $\mathrm{pH} 7.4,150 \mathrm{mM}$ $\mathrm{NaCl}, 0.1 \%$ Tween-20) 3 times. The beads were then equilibrated with TBST for overnight. After decanting TBST, the resulting beads were incubated with E. coli. lysate $(6.5 \mathrm{mg} / \mathrm{mL})$ and $2 \%$ bovine 
serum albumin (BSA) in TBST at room temperature for $1 \mathrm{~h}$. The beads were subsequently incubated with anti-FLAG ${ }^{\circledR}$ monoclonal M2 antibody (Sigma, 1/5,000 dilution) for $1 \mathrm{~h}$ at room temperature. After

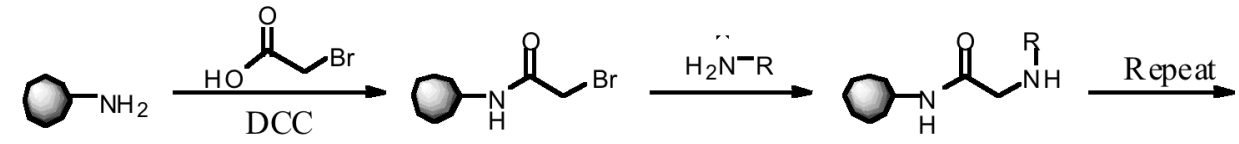

TentaGel beads
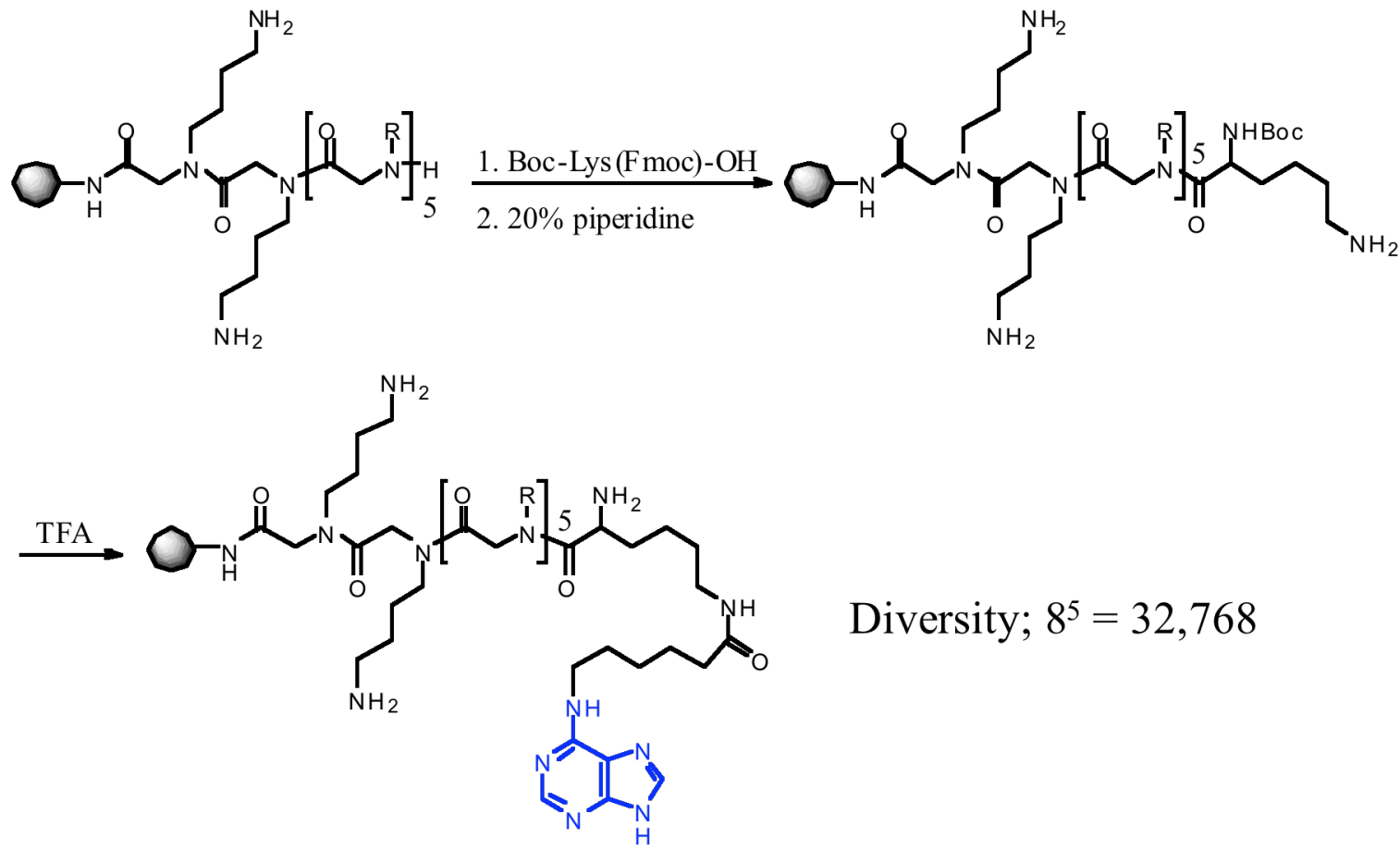

Diversity; $8^{5}=32,768$



Figure S1. Synthetic scheme for purine-capped peptoid library and chemical structures of the amines used.

washing with TBST $(3 \times 1 \mathrm{~mL})$, the beads were treated with Qdot $^{\circledR}$ 655-coated secondary antibody (Quantum Dot Corp, 1/200 dilution) in the presence of E. coli. lysate $(6.5 \mathrm{mg} / \mathrm{mL}$ ) and $2 \%$ BSA in 
TBST at room temperature for $1 \mathrm{~h}$. The buffer was removed and washed with TBST $(3 \times 1 \mathrm{~mL})$. The peptoids that bind the anti-FLAG ${ }^{\circledR}$ M2 monoclonal antibody or Qdot ${ }^{\circledR}$ 655-coated secondary antibody directly were visualized under a fluorescence microscope by irradiation of the beads through a DAPI filter (390-410 nm band pass filter), and the red-emitting beads were removed using a micropipette. The remaining beads were then incubated with yeast lysate containing the $26 \mathrm{~S}$ proteasome $(\sim 5 \mathrm{nM})$ in the presence of $E$. coli lysate $(6.5 \mathrm{mg} / \mathrm{mL})$ and $2 \%$ BSA in TBST at RT for $2 \mathrm{~h}$. Again the beads were subsequently treated with anti-FLAG ${ }^{\circledR} \mathrm{M} 2$ monoclonal antibody (1/5,000 dilution) for $1 \mathrm{~h}$ at $\mathrm{RT}$ and Qdot $^{\circledR}$ 655-coated secondary antibody (1/200 dilution) for $1 \mathrm{~h}$ at RT. The buffer was removed and the beads were washed with TBST $(3 \times 1 \mathrm{~mL})$. The red-shining beads were again visualized and picked as described above. The three beads scored as hits were heated at $95^{\circ} \mathrm{C}$ in $1 \%$ SDS for 20 min. The beads were then washed successively with $\mathrm{PBS}$ ( $\mathrm{pH} 7.4$, twice) and $\mathrm{H}_{2} \mathrm{O}$ (three times). The washed beads were then subjected to automated on-bead Edman sequencing analysis.

Resynthesis of RIP-1 and C2. The peptoids, Nlys-Nlys-Nmba-Nleu-Nleu-Ntrp-Nlys and Nser-NlysNlys-Nleu-Nlys were synthesized on Rink Amide MBHA resin (Novabiochem) using a microwaveassisted protocol in a scale of $0.1 \mathrm{mmol}$, respectively $(1,2)$. At the end of the peptoid synthesis, BocLys(Fmoc)-OH (Novabiochem) was attached to the N-terminal of the peptoid by standard peptide synthesis using Fmoc chemistry. The Fmoc protecting group was removed by $20 \%$ piperidine in DMF. For the synthesis of RIP-1, the resulting free amino group, Nlys-Nlys-Nmba-Nleu-Nleu-Ntrp-NlysLysine, was coupled with 6-(9H-purin-6-ylamino)hexanoic acid under the same condition described in the procedure for the library synthesis. The resulting conjugate was cleaved from the resin by $95 \%$ TFA, $2.5 \%$ water, and $2.5 \%$ triisopropylsilane (cleavage cocktail) at room temperature for $2 \mathrm{~h}$. For the synthesis of $\mathrm{C} 2$, the resulting free amine having Nser-Nlys-Nlys-Nleu-Nlys-Lysine was cleaved from the resin by cleavage cocktail. TFA was removed and the crude products were purified by C18 RPHPLC. The identities of RIP-1 and C2 were confirmed by MALDI-TOF analysis: RIP-1: observed 1348.6, expected 1348.8 for $\mathrm{C}_{69} \mathrm{H}_{109} \mathrm{~N}_{14} \mathrm{O}_{9}+\mathrm{H}$. C2: observed 743.5, expected 743.5 for $\mathrm{C}_{34} \mathrm{H}_{69} \mathrm{~N}_{11} \mathrm{O}_{7}+\mathrm{H}$.

Affinity purification of the $26 \mathrm{~S}$ proteasome. Affinity-purified $26 \mathrm{~S}$ proteasome was prepared from $S$. cerevisiae strain RJD1144 (MATa his3:200 leu2-3, 112 lys2-801 trp 63 PRE1 FLAG::Ylplac211 (URA3) as described previously (3) with minor modification (4). The protocol involves purification of the $26 \mathrm{~S}$ proteasome carrying a FLAG tag on the C-terminus of the Pre1 protein ( $\beta 4$ subunit) by immunoaffinity chromatography and FLAG ${ }^{\circledR}$ peptide (Sigma) elution.

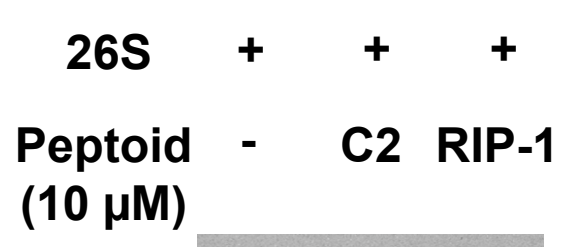

\section{$\alpha-$ Gal4}

Figure S2. Chaperonin assay (see Fig. 3A) comparing the effects of $\mathrm{C} 2(10 \mu \mathrm{M})$ and RIP-1 $(10 \mu \mathrm{M})$ (see Fig. $2 \mathrm{C}$ of the paper for structures). The gel is a Western blot showing the amount of Gal4VP16 remaining on the beads. C2 is a control peptoid that was not selected as a proteasome ligand. 
Chaperonin Activity Assay. The chaperonin activity assay has been described previously (5) with the following changes. The activator-DNA complex was added at a $60 \mathrm{nM}$ final concentration of activatorDNA complex to the reaction mix containing $25 \mathrm{nM} 26 \mathrm{~S}$ proteasome pre-incubated for 15 minutes at RT with the indicated amount of RIP- 1 or C2, $3 \mathrm{mM}$ ATP, and $1 \mu \mathrm{M}$ non-biotinylated DNA containing Gal4 binding sites in TR reaction buffer (10 mM HEPES (pH 7.8) $50 \mathrm{mM} \mathrm{KCl,} 6.25 \mathrm{mM} \mathrm{MgCl} 2,0.1$ mM EDTA, $1 \mathrm{mM}$ DTT). After the assay, the samples were run on SDS-PAGE and Western blotted with an antibody raised against the Gal4 DBD. The bands were analyzed by "ImageJ" software for quantification.

Cell Culture and Western Blot. HeLa cells $\left(3 \times 10^{4}\right)$ were placed in 6-well plate and grown in Dulbecco's modified Eagle medium (Invitrogen) supplemented with 10\% fetal calf serum (Invitrogen) for $48 \mathrm{~h}$. After incubation with the indicated concentration of RIP-1, C2 and MG132, cells were lysed in $1 \% \mathrm{SDS} / 10 \mathrm{mM}$ Tris- $\mathrm{HCl}, \mathrm{pH}$ 7.5. Protein concentration was measured using BCA protein assay reagent (Pierce). Equal amount of protein samples $(25 \mu \mathrm{g})$ were subjected to $10 \%$ SDS-PAGE and transferred to a PVDF membrane (Immobilon-P, Millipore). The membranes with transferred proteins were blocked with TBST containing 5\% non-fat, dried milk and then incubated with anti-p27 Kip1 antibody (Cell Signaling) and subsequently secondary antibody labeled with horseradish peroxidase. Signals were visualized by enhanced chemiluminescence detection system (Amersham Pharmacia Biotech). The bands were analyzed by "ImageJ" software for quantification.

\section{References}

1. Alluri, P. G.; Reddy, M. M.; Bacchawat-Sikder, K.; Olivos, H. J.; Kodadek, T. J. Amer. Chem. Soc. 2003, 125, 13995-14004.

2. Olivos, H. J.; Alluri, P. G.; Reddy, M. M.; Saloney, D.; Kodadek, T. Org. Lett. 2002, 4, 4057-4059.

3. Verma, R.; Chen, S.; Feldman, R.; Schieltz, D.; Yates, J.; Dohmen, J.; Deshaies, R. J. Mol. Biol. Cell 2000, 11, 3425-3439.

4. Ferdous, A.; Gonzalez, F.; Sun, L.; Kodadek, T.; Johnston, S. A. Mol. Cell 2001, 7, 981-991.

5. Ferdous, A.; Sikder, D.; Gillette, T.G.; Nalley, K.; Kodadek, T.; Johnston, S. A. Gene. Dev. 2007, 21, 112-123. 